\title{
Pattern of Retinal Nerve Fiber Layer Thickness Loss in Fetal Alcohol Syndrome: A Spectral-Domain Optical Coherence Tomography Analysis
}

\author{
Padrão de Perda da Espessura da Camada de Fibras \\ Nervosas da Retina na Síndrome Fetal-Alcoólica: Análise \\ com Tomografia de Coerência Ótica de Domínio Espectral
}

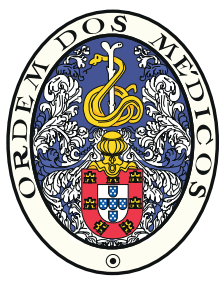

\author{
Carlos MENEZES $\triangle^{1}$, Isabel RIBEIRO ${ }^{1}$, Pedro COELHO ${ }^{1}$, Catarina MATEUS ${ }^{1}$, Carla TEIXEIRA ${ }^{1}$ \\ Acta Med Port 2016 Apr;29(4):254-260 - http://dx.doi.org/10.20344/amp.6871
}

\section{ABSTRACT}

Introduction: Optic disc hypoplasia is a common feature in fetal alcohol syndrome. Thus, we aimed to evaluate the optic disc morphology changes and the peripapillary retinal nerve fiber layer thickness in these patients.

Material and Methods: We performed spectral-domain optical coherence tomography in a cohort of 11 patients (22 eyes) with fetal alcohol syndrome and in an age-matched control group. We evaluated optic nerve head parameters (optic disc area and diameter, rim area, cup/disc horizontal and vertical ratios) and peripapillary retinal nerve fiber layer thickness.

Results: Mean optic disc area, rim area and optic disc diameter were, respectively, in fetal alcohol syndrome patients and control subjects: $1.540 \pm 0.268$ and $1.748 \pm 0.326 \mathrm{~mm}^{2} ; 1.205 \pm 0.286$ and $1.461 \pm 0.314 \mathrm{~mm}^{2} ; 1.417 \pm 0.124$ and $1.501 \pm 0.148 \mathrm{~mm}(p<0.05)$. We found no significant differences between groups for cup/disc ratios. Mean retinal nerve fiber layer thickness was significantly lower in fetal alcohol syndrome patients $(90.500 \pm 9.344 \mu \mathrm{m})$ as compared to controls $(111.000 \pm 7.855 \mu \mathrm{m})(p<0.0001)$. Analysis showed a significant decrease in retinal nerve fiber layer thickness for the superior, inferior and nasal quadrants $(p<0.005)$. The temporal quadrant showed no significant differences.

Discussion: Optic disc area, rim area and optic disc diameters were significantly reduced in fetal alcohol syndrome patients. Although mean peripapillary retinal nerve fiber layer thickness was decreased, the temporal quadrant was spared.

Conclusion: In addition to a smaller optic disc area/ diameter and rim area, we found a heterogeneous peripapillary retinal nerve fiber layer thickness loss in fetal alcohol syndrome patients with sparing of the temporal quadrant. Spectral-domain optical coherence tomography may be useful to determine the presence of fetal alcohol syndrome status.

Keywords: Fetal Alcohol Spectrum Disorders; Optic Nerve Diseases; Nerve Fibers; Retina.

\section{RESUMO}

Introdução: A hipoplasia do disco ótico é característica comum na síndrome fetal-alcoólica. Assim, propusemo-nos a avaliar as alterações morfológicas do disco ótico e a espessura da camada de fibras nervosas retinianas peripapilares, nunca antes estudada nestes doentes.

Material e Métodos: Realizamos tomografia de coerência óptica de domínio espectral num grupo de 11 doentes (22 olhos) com síndrome fetal-alcoólica e num grupo controlo ajustado à idade. Avaliamos alguns parâmetros morfológicos do disco ótico (área e diâmetro do disco ótico, área do anel neurorretiniano, razão escavação/disco horizontal e vertical) e a espessura da camada de fibras nervosas retiniana peripapilares.

Resultados: Os valores médios da área do disco ótico, anel neurorretiniano e diâmetro do disco ótico foram, respetivamente, no grupo de doentes e no grupo controlo: $1,540 \pm 0,268$ e 1,748 \pm 0,326 mm²; 1,205 \pm 0,286 e 1,461 $\pm 0,314 \mathrm{~mm}^{2} ; 1,417 \pm 0,124$ e 1,501 $\pm 0,148 \mathrm{~mm}(p<0,05)$. Não encontramos diferenças significativas entre as razões escavação/disco. A espessura média da camada de fibras nervosas foi significativamente menor nos pacientes $(90,500 \pm 9,344 \mu \mathrm{m})$ relativamente aos controlos $(111,000 \pm 7,855 \mu \mathrm{m})$ $(p<0,0001)$. Verificamos uma diminuição significativa nos quadrantes superior, inferior e nasal $(p<0,005)$. O quadrante temporal não revelou diferenças significativas.

Discussão: As áreas do disco ótico e anel neurorretiniano e o diâmetro do disco ótico foram significativamente menores nos pacientes com síndrome fetal-alcoólica. Embora a espessura média da camada de fibras nervosas peripapilares se tenha revelado diminuída, o quadrante temporal parece estar poupado.

Conclusão: Para além de uma área/ diâmetro do disco ótico e área do anel neurorretiniano menores, descobrimos um padrão heterogéneo de perda da camada de fibras nervosas retinianas peripapilares em pacientes com síndrome fetal-alcoólica, sem atingimento do quadrante temporal. A tomografia de coerência óptica poderá ser útil no estabelecimento do diagnóstico da síndrome fetal-alcoólica. Palavras-chave: Doenças do Nervo Óptico; Fibras Nervosas; Retina; Tomografia de Coerência Óptica; Transtornos do Espectro Alcoólico Fetal.

\section{INTRODUCTION}

Fetal alcohol syndrome (FAS) is the most severe manifestation of fetal alcohol spectrum disorders and represents the leading non-hereditary cause of mental retardation and physical birth defects in the western world. ${ }^{1}$

FAS prevalence was estimated to be 0.97 cases per 1000 live births in Europe, ${ }^{2}$ but varies widely worldwide, from 0.1 cases per 1000 live-births in Japan ${ }^{3}$ to 74.2 cases per 1000 children of school-aging in South Africa. ${ }^{4}$

\footnotetext{
1. Ophthalmology Department. Hospital Pedro Hispano. Matosinhos. Portugal.

$\triangle$ Autor correspondente: Carlos Menezes. cafsousamenezes@gmail.com

Recebido: 02 de agosto de 2015 - Aceite: 02 de novembro de 2015 | Copyright @ Ordem dos Médicos 2016
} 
FAS diagnosis is based on the presence of characteristic facial dimorphism, pre and postnatal growth retardation and functional or structural central nervous system deficits. ${ }^{5}$ The eye is, among several organic systems, one of the most affected structures by alcohol misuse during pregnancy. Independently of the exposition to high levels of alcohol prenatally, the risk of eye malformations seems to be limited to children who develop FAS. ${ }^{6}$

Ocular findings occur in up to $90 \%$ of FAS patients ${ }^{7}$ and all eye structures may be affected with a wide variety of severity. External ocular signs include short horizontal palpebral fissure, epicanthus, hypertelorism, blepharoptosis, telecanthus, strabismus and nystagmus. ${ }^{7-10}$ Intraocular signs most commonly include optic disc hypoplasia, tortuosity of retina vessels, microphthalmus and impaired vision and also cataract, other anterior segment abnormalities, and coloboma. $^{7-10}$

Alcohol-induced optic disc hypoplasia is a common feature in FAS, which is estimated to occur in up to $48 \%$ of FAS children. ${ }^{9}$ It is characterized by a decreased number of optic nerve axons with morphologic signs that can vary from subtle pallor, irregular margins and abnormal vasculature to evident small size with the presence of the classic doublering sign. ${ }^{7,11}$ Optic nerve hypoplasia pathogenesis in the context of FAS is complex and not yet fully understood. Recent animal studies have implicated alcohol interference with the Sonic hedgehog pathway ${ }^{1}$ and with glia cells ability to modulate neural development and function. ${ }^{12}$ Alcohol inhibits astrocyte-mediated neuritogenesis and oligodendrocyte development, survival and myelination and activates microglia cells increasing oxidative stress and alcohol induced neuronal apoptosis. ${ }^{12}$ These findings corroborate previous animal studies, which found loss of retinal ganglion cells and optic axons, delayed gliogenesis and myelination and a smaller optic nerve cross sectionalarea and retinal thickness as a result in FAS models. ${ }^{13-16}$
The diagnosis of optic disc hypoplasia can be difficult because the optic disc can be only slightly reduced in size. Methods used to make the diagnosis of optic disc hypoplasia include measuring the DM/DD ratio (ratio between the centre of the optic disc and the fovea centralis, divided per the mean diameter of the optic disc, ${ }^{17}$ digital fundus analysis ${ }^{18,19}$ and the presence of the double ring sign, the last one only diagnosing the most severe cases. ${ }^{20}$ To date, a few studies used optical coherence tomography (OCT) in optic disc hypoplasia evaluation. Recently, in a prospective comparative study using spectral domainoptical coherence tomography (SD-OCT), Pilat el al found that this imaging technique was very useful in optic disc hypoplasia diagnosis. ${ }^{21}$

This work was designed to determine if SD-OCT detects the optic disc morphology changes present in FAS patients and to measure the peripapillary retinal nerve fiber layer (RNFL) thickness, in order to establish the presence and the pattern of axonal loss.

\section{MATERIALS AND METHODS}

\section{Study population}

Eleven patients ( 6 male/ 5 female; $n=22$ eyes; mean age $\pm \mathrm{SD}=20.73 \pm 3.60$ years) with the diagnosis of complete FAS previously established by the paediatric development department were observed in ophthalmology consultation of Pedro Hispano Hospital between January and March of 2015. These patients were included in the study and compared with an age-matched group of 14 controls (5 male/ 9 female; $n=28$ eyes; mean age $\pm S D=22.82 \pm 4.31$ years). Control subjects had best-corrected visual acuity (BCVA) of 1.0 in both eyes and normal ophthalmological examination. ANOVA showed no significant age difference between groups.

All participants underwent an ophthalmic examination, BCVA obtained with Snellen decimal scale, slit lamp

Table 1 - Demographic characteristics and clinical data of the fetal alcohol syndrome patients

\begin{tabular}{|c|c|c|c|c|c|c|c|}
\hline Patient & $\begin{array}{c}\text { Age } \\
\text { (years) }\end{array}$ & Gender & $\begin{array}{l}\text { BCVA } \\
\text { (RE/LE) }\end{array}$ & $\begin{array}{l}\text { Double-ring } \\
\text { sign }\end{array}$ & $\begin{array}{c}\text { Retinal vessel } \\
\text { tortuosity }\end{array}$ & $\begin{array}{c}\text { Mean RNFL } \\
\text { thickness }(\mu \mathrm{m}) \\
(\mathrm{RE} / \mathrm{LE})\end{array}$ & $\begin{array}{c}\text { Optic disc area } \\
\left(\mathrm{mm}^{2}\right) \\
(\mathrm{RE} / \mathrm{LE})\end{array}$ \\
\hline 1 & 16 & Male & $1.0 / 0.8$ & No & Yes & $83 / 81$ & $1.34 / 1.27$ \\
\hline 2 & 25 & Male & $0.9 / 0.8$ & No & No & $105 / 101$ & $1.45 / 1.84$ \\
\hline 3 & 17 & Female & $1.0 / 1.0$ & No & Yes & $98 / 97$ & $1.45 / 1.81$ \\
\hline 4 & 19 & Male & $0.6 / 0.6$ & No & Yes & $85 / 87$ & $1.49 / 1.85$ \\
\hline 5 & 19 & Female & $1.0 / 1.0$ & No & Yes & $94 / 97$ & $1.17 / 1.15$ \\
\hline 6 & 26 & Male & $0.8 / 0.8$ & Yes (RE + LE) & Yes & $68 / 71$ & $1.54 / 1.23$ \\
\hline 7 & 23 & Female & $1.0 / 1.0$ & No & No & $91 / 86$ & $1.49 / 1.40$ \\
\hline 8 & 20 & Male & $1.0 / 1.0$ & No & No & $88 / 83$ & $1.50 / 1.55$ \\
\hline 9 & 17 & Female & $1.0 / 1.0$ & No & No & $95 / 96$ & $1.84 / 1.83$ \\
\hline 10 & 26 & Male & $1.0 / 1.0$ & No & Yes & $96 / 93$ & $1.91 / 2.10$ \\
\hline 11 & 20 & Female & $1.0 / 1.0$ & No & Yes & $99 / 97$ & $1.30 / 1.38$ \\
\hline
\end{tabular}

BCVA: best-corrected visual acuity; RNFL: retinal nerve fiber layer; RE: right eye; LE: left eye 
examination of the anterior segment, retinal examination and optic disc evaluation. All individuals were also submitted to an optic nerve head morphometric analysis and a peripapillary RNFL examination, using a SD-OCT.

Exclusion criteria included the following: retinal diseases, diabetes even in the absence of retinopathy, high ametropy (spherical equivalent between -4 and +4 diopters) and inability to cooperate in OCT examination.

Informed consent was obtained from all participants older than 18 years of age and from parents/ guardians in the case of participants younger than 18 years, after detailed exposure of the purpose of the study. The research was approval by our local ethics committee and it was conducted in accordance with the tenets of the Declaration of Helsinki.

\section{Spectral-domain optical coherence tomography (SD-OCT)}

In this study we used SD-OCT Copernicus (OPTOPOL Technology SA, Poland) to obtain optic nerve head and peripapillary RNFL thickness measurements. This system operates with a scanning speed of 25.000 A-scans per second and a resolution of $6 \mu \mathrm{m}$.

We evaluated optic nerve head parameters, namely mean optic disc area, rim area, mean optic disc diameter, cup/ disc horizontal and vertical ratios, using a 3D protocol. Concerning RNFL measurements, a circular scan (ring diameter $2.4 \mathrm{~mm}$; ring thickness $0.4 \mathrm{~mm}$ ) centered on the optic nerve head was used and peripapillary RNFL thickness sectors were evaluated (superior, inferior, nasal and temporal).

\section{Statistical analysis}

Statistical analysis was performed using StatView statistical software package (SAS Cary, NC, USA). After verifying the normality of the data across the study groups, we used a parametric analysis (ANOVA between-group effects) for overall means comparison and Fisher's PLSD post-hoc test for multiple comparisons. Significance was settled for $p<0.05$. Descriptive statistics are presented as a mean \pm standard deviation (SD).

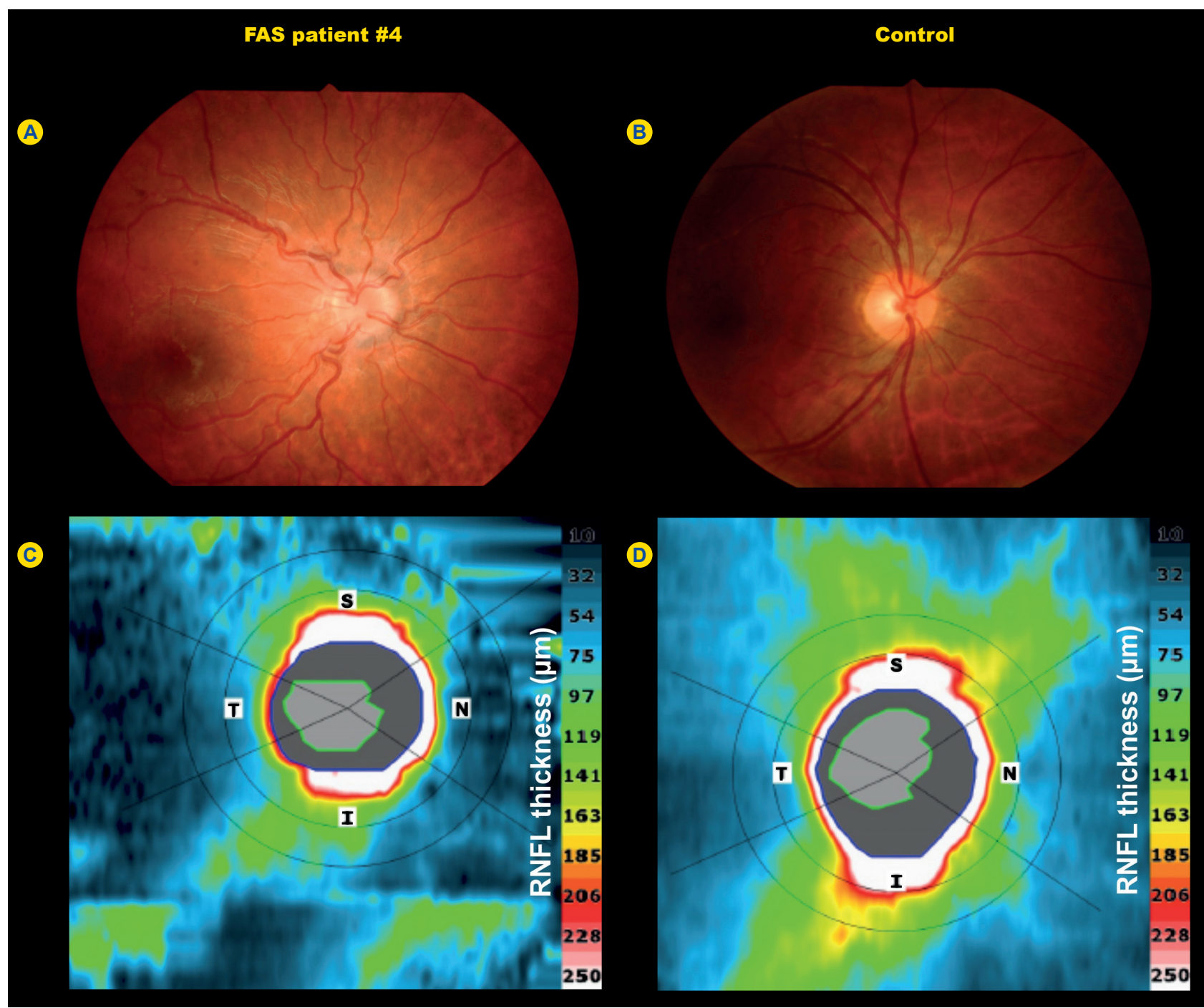

Figure 1 - Representative optic disc fundus photography (A and B) and OCT peripapillary RNFL thickness map (C and D) of a FAS patient $(\# 4)$ and a control subject. Figures $A$ and $C$ correspond to the patient (\#4) and figures $B$ and $D$ to the control subject. $\mathrm{S}$ : superior; T: temporal; I: inferior; $\mathrm{N}$ : nasal. 


\section{RESULTS}

\section{FAS group clinical data}

All patients with FAS had neurodevelopment and growth delay, learning difficulties and FAS typical facial features. Concerning ocular findings, best-corrected visual acuity (BCVA) ranged from 0.6 to 1.0 (mean $\pm S D=0.9 \pm 0.1$ ) and cycloplegic spherical equivalent ranged from -3.88 to +0.50 diopters (mean $\pm S D=-0.80 \pm 1.00$ ). None of the patients had manifest strabismus. Six patients $(54,5 \%)$ showed exophoria. Convergence insufficiency was present in four patients (36\%). Abnormal external ocular features encountered were short palpebral fissure $(72.7 \%)$, epicanthus (27\%), telecanthus $(27 \%)$ and antimongoloid slant (9\%). No anterior segment abnormalities were found. Fundus photography revealed retinal vascular tortuosity in seven patients (63.6\%) and double ring optic disc sign, a clinical marker of severe optic disc hypoplasia, in both eyes of one patient (9\%) (see clinical data in Table 1 and a representative example in Fig. $1 \mathrm{~A}$ ). Axial length measured through partial coherence interferometry (IOLMaster, Carl Zeiss, Germany) ranged from 20.01 to $22.90 \mathrm{~mm}$ (mean \pm $\mathrm{SD}=21.96 \pm 0.8$.

\section{Assessment of peripapillary RNFL thickness}

We found a significant group effect on mean peripapillary RNFL thickness $(p<0.0001)$ (see a representative example in Fig. $1 \mathrm{~B}$ ). Patients with FAS showed a decreased RNFL thickness, which was significant for superior $(p<0.0001)$, inferior $(p<0.0001)$ and nasal $(p=0.0031)$ quadrants, as compared to control participants (see Table 2 and Fig. 2). The temporal quadrant showed no significant differences between groups.

\section{Optic nerve head morphometric analysis}

Mean optic disc and rim areas were significantly lower in patients with FAS ( $p=0.0198$ and $p=0.0046$, respectively), as compared to control group (Fig. 3).

We also found a significant decrease in mean optic disc diameter $(p=0.0382)$, unlike the cup/ disc horizontal and vertical ratios that showed no significant differences between patients with FAS and controls (see Table 2).

\section{DISCUSSION}

In this study, we performed for the first time an optic nerve head morphometric analysis and a peripapillary RNFL examination in FAS patients, using SD-OCT. We also established a pattern of axonal loss. This finding may be useful to further determine the presence of FAS status.

It is known that OCT, particularly spectral domain new generation, is a powerful and widespread tool in neurophthalmology practice. However, although OCT is actually being used in the assessment of the optic disc morphometry and RNFL and ganglion cell layer thicknesses in many diseases, to the best of our knowledge, there are no studies of its utility in FAS. Our study aimed to evaluate optic disc morphometry and RNFL thickness in a cohort of FAS patients and compare these structural data with a control age-matched group.

We found that both optic disc and rim areas and optic disc diameter were statistically lower in FAS patients than in control group. Our study confirmed the findings of previous studies with FAS children, which found that these patients have smaller optic discs than normal individuals of the same age. ${ }^{7,8,10,11,17,18}$ Unlike the other FAS studies, our sample consists of a group of young adults with similar ages (16 - 26 years), which increases the strength of our results,

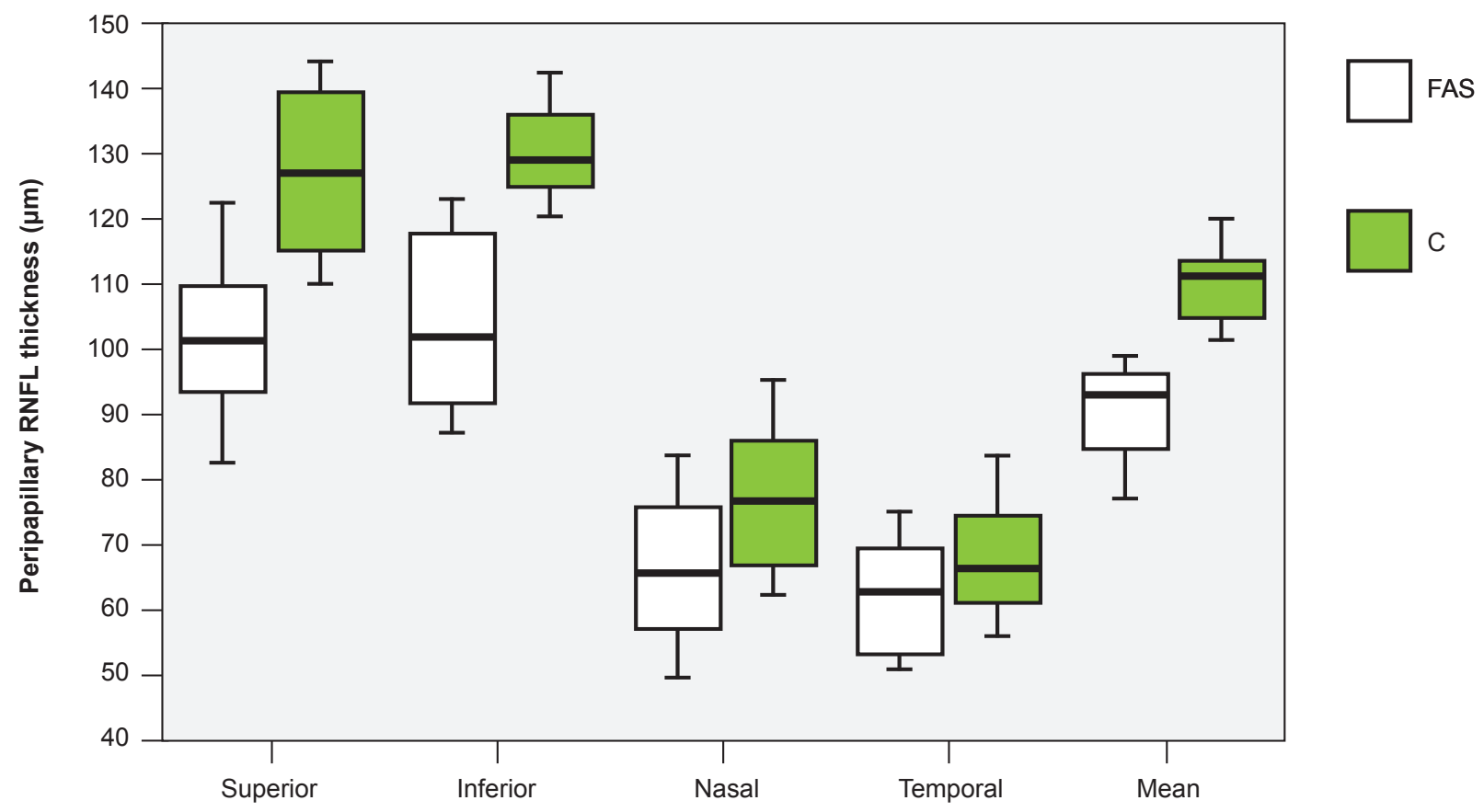

Figure 2 - Peripapillary retinal nerve fiber layer thickness. Superior, inferior and nasal quadrants are significantly decreased in fetal alcohol syndrome group, being the temporal quadrant the most spared. 


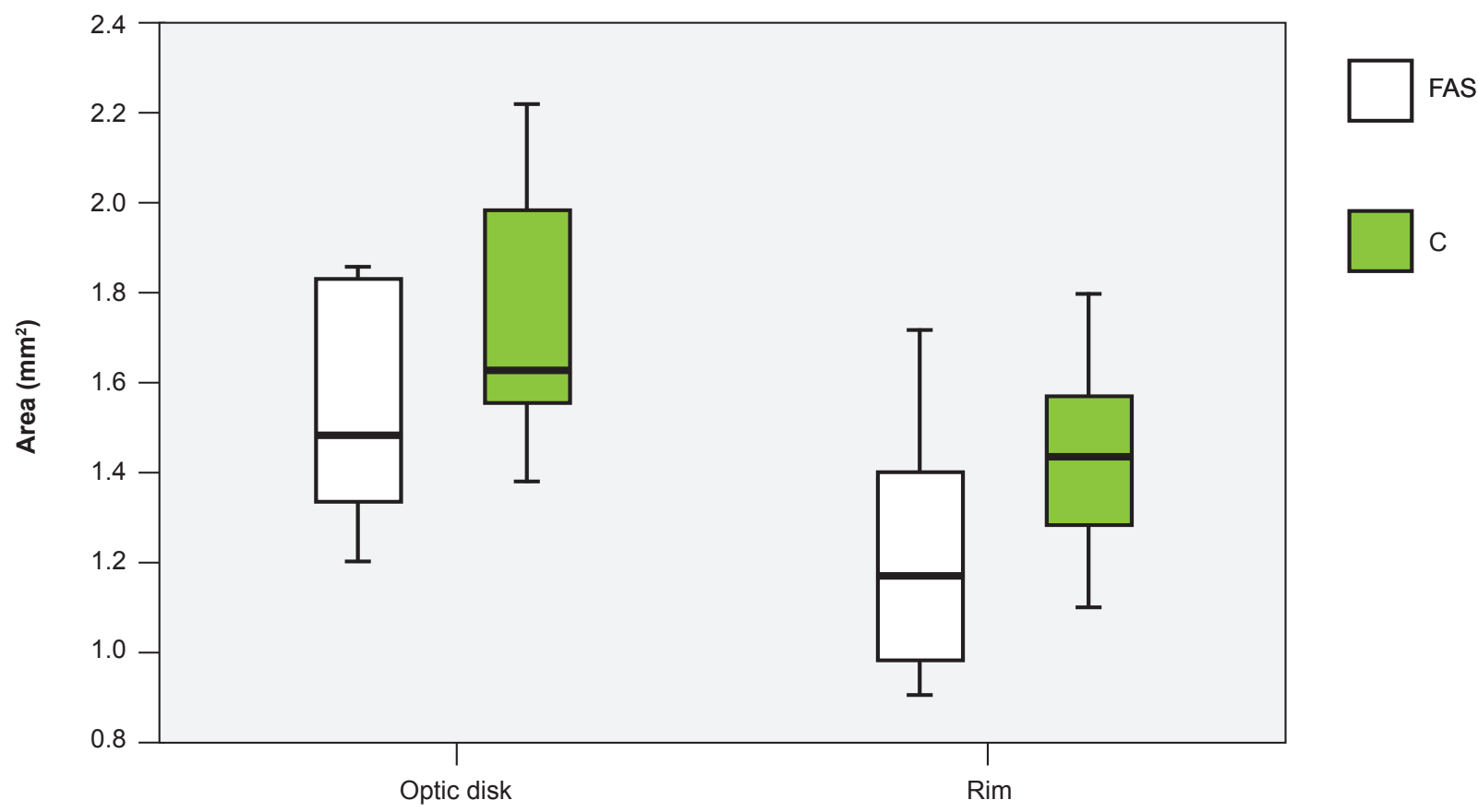

Figure 3 - Mean optic disc area and rim area. Significant impairment is observed for both areas in patients with fetal alcohol syndrome, comparing with controls.

since we potentially reduced the more pronounced optic disc morphometric variation that occurs in childhood with aging.

Our results also showed that FAS patients have reduced peripapillary RNFL thickness. Optic disc hypoplasia in FAS animal studies was explained by the loss of retinal ganglion cells and their axons and delayed gliogenesis and myelination in the developing embryologic and fetal periods. $^{14,22}$ In the light of these findings, RNFL thickness decrease was an expectable result. Because the more severe cases of FAS were not included in this study due to poor cooperation in the context of severe mental retardation, it seems logical that these differences between healthy and FAS subjects may be even greater.

Although the FAS patients showed smaller disc diameters (FAS mean diameter $=1.417 \mathrm{~mm}$; control group mean diameter $=1.501 \mathrm{~mm}$ ) and consequently an increased distance from the optic disc margin to the area of RNFL measurement, we do believe that this fact could only influence the RNFL thickness measurements into a small and overall extent.

All patients had subnormal optic disc areas, however only a single patient had the classical optic disc double-ring sign in both eyes, which is associated with the most severe cases of optic disc hypoplasia (see Table 1). The most common finding in fundus photography was, as reported by previous studies, ${ }^{7,11}$ increased vascular tortuosity $(63,6 \%)$, which was most often accompanied by subtle pallor and/ or irregular margins (see Table 1). As subnormal optic disc areas may be undetectable by fundus photography, OCT analysis is essential in the evaluation of optic disc hypoplasia associated with FAS. ${ }^{21}$

Pilat et al showed that peripapillary RNFL thickness was homogeneously reduced in patients with optic disc hypoplasia. ${ }^{21}$ Our results showed that although RNFL thickness was reduced in FAS patients, this reduction was not homogeneous in the whole peripapillary area. Sectorial analysis of the peripapillary RNFL per quadrants showed statistical significant differences in the inferior, superior and nasal quadrants, but not in the temporal quadrant. These findings suggest that alcohol teratogenicity responsible for optic disc hypoplasia may be heterogeneous with relative sparing of the temporal peripapillary RNFL. The preservation of the papillomacular bundle may explain the relatively good visual acuities of our FAS patients, which ranged between 0.6 and 1.0, despite the presence of optic disc subnormal areas.

Visual impairment in FAS is variable among different studies, ${ }^{7,8,10,23}$ with BCVA ranging from less than 0.2 in a considerable percentage of patients ${ }^{7}$ to $1.0 .{ }^{23}$ Our sample of patients showed moderate to minimal visual impairment, being the worse BCVA of 0.6. There are some reasons that may explain this situation:

1) the most severe cases of FAS with potentially worse visual performance were not included in this study;

2) patients with potentially amblyopic ametropias were excluded in an attempt to minimize possible effects of axial length and refractive error on measurements of RNFL thickness; ${ }^{24,25}$

3) these patients were followed and appropriately managed yearly since their early childhood in our ophthalmologic consultation. ${ }^{10}$

\section{CONCLUSIONS}

SD-OCT plays an important role in ophthalmic characterization of FAS patients, helping to detect subnormal 
Table 2 -Spectral-domain optical coherence tomography data of patients with fetal alcohol syndrome and control participants

\begin{tabular}{|c|c|c|c|}
\hline Parameters & FAS group & Control group & $p$ value \\
\hline \multicolumn{4}{|c|}{ Mean optic disc area $\left(\mathrm{mm}^{2}\right)$} \\
\hline Mean \pm SD & $1.540 \pm 0.268$ & $1.748 \pm 0.326$ & \multirow[t]{2}{*}{0.0198} \\
\hline Range & {$[1.15 ; 2.10]$} & {$[1.20 ; 2.49]$} & \\
\hline \multicolumn{4}{|l|}{ Rim area $\left(\mathrm{mm}^{2}\right)$} \\
\hline Mean \pm SD & $1.205 \pm 0.286$ & $1.461 \pm 0.314$ & \multirow[t]{2}{*}{0.0046} \\
\hline Range & {$[0.71 ; 1.77]$} & {$[0.80 ; 2.27]$} & \\
\hline \multicolumn{4}{|c|}{ Mean optic disc diameter (mm) } \\
\hline Mean \pm SD & $1.417 \pm 0.124$ & $1.501 \pm 0.148$ & \multirow[t]{2}{*}{0.0382} \\
\hline Range & {$[1.24 ; 1.67]$} & {$[1.20 ; 1.80]$} & \\
\hline \multicolumn{4}{|c|}{ Cup/ disc horizontal ratio } \\
\hline Mean \pm SD & $0.400 \pm 0.211$ & $0.329 \pm 0.191$ & \multirow[t]{2}{*}{ n.s. } \\
\hline Range & {$[0.00 ; 0.71]$} & {$[0.00 ; 0.61]$} & \\
\hline \multicolumn{4}{|c|}{ Cup/ disc vertical ratio } \\
\hline Mean \pm SD & $0.415 \pm 0.212$ & $0.352 \pm 0.199$ & \multirow[t]{2}{*}{ n.s. } \\
\hline Range & {$[0.00 ; 0.73]$} & {$[0.00 ; 0.61]$} & \\
\hline \multicolumn{4}{|c|}{ RNFL superior quadrant $(\mu \mathrm{m})$} \\
\hline Mean \pm SD & $102.455 \pm 13.204$ & $127.500 \pm 13.492$ & \multirow[t]{2}{*}{$<0.0001$} \\
\hline Range & {$[78 ; 127]$} & {$[106 ; 151]$} & \\
\hline \multicolumn{4}{|c|}{ RNFL inferior quadrant $(\mu \mathrm{m})$} \\
\hline Mean \pm SD & $103.864 \pm 15.887$ & $131.107 \pm 11.538$ & \multirow[t]{2}{*}{$<0.0001$} \\
\hline Range & {$[74 ; 139]$} & {$[108 ; 168]$} & \\
\hline \multicolumn{4}{|c|}{ RNFL nasal quadrant $(\mu \mathrm{m})$} \\
\hline Mean \pm SD & $66.727 \pm 12.969$ & $77.750 \pm 11.974$ & \multirow[t]{2}{*}{0.0031} \\
\hline Range & {$[44 ; 88]$} & {$[62 ; 103]$} & \\
\hline \multicolumn{4}{|c|}{ RNFL temporal quadrant $(\mu \mathrm{m})$} \\
\hline Mean \pm SD & $63.000 \pm 10.876$ & $68.679 \pm 10.242$ & \multirow[t]{2}{*}{ n.s. } \\
\hline Range & {$[42 ; 87]$} & {$[54 ; 90]$} & \\
\hline \multicolumn{4}{|c|}{ RNFL average $(\mu \mathrm{m})$} \\
\hline Mean \pm SD & $90.500 \pm 9.344$ & $111.000 \pm 7.855$ & \multirow[t]{2}{*}{$<0.0001$} \\
\hline Range & {$[68 ; 115]$} & {$[97 ; 133]$} & \\
\hline
\end{tabular}

n.s.: not significant

optic disc areas and reduced RNFL thickness. Our results suggest that temporal RNFL quadrant, corresponding to papillomacular bundle, may be less affected by alcohol teratogenic effect than other quadrants, which may explain the relative good visual acuities associated with this type of optic disc hypoplasia. This pattern of RNFL commitment may be useful to further determine the presence of FAS status and in the differential diagnosis between FAS and other optic disc neuropathies. Further studies with larger samples are necessary to get insight on the role of these structural measures as potential biomarkers of FAS status and eventually relate them with functional measures, namely retinal ganglion cells function, chromatic contrast sensitivities and visual field measurements. Since retinal ganglion cells are key players in the processing of visual information to the visual cortex, it would be interesting to use magnetic resonance imaging and measure cortical thickness of retinotopically mapped visual cortical areas in FAS patients.

\section{MEETING PRESENTATION}

This paper contains original data not previously presented in any previous meeting or congress.

\section{PROTECTION OF HUMANS AND ANIMALS}

The authors declare that the procedures were followed according to the regulations established by the Clinical Research and Ethics Committee and to the Helsinki Declaration of the World Medical Association.

\section{DATA CONFIDENTIALITY}

The authors declare having followed the protocols in use at their working center regarding patient's data publication.

\section{CONFLICTS OF INTEREST}

The authors don't have any conflict of interest to declare.

\section{FUNDING SOURCES}

No subsidies or grants contributed to this work. 


\section{REFERENCES}

1. Brennan D, Giles S. Ocular involvement in fetal alcohol spectrum disorder: a review. Curr Pharm Des. 2014;20:5377-87.

2. Abel EL. An update on incidence of FAS: FAS is not an equal opportunity birth defect. Neurotoxicol Teratol. 1995;17:437-43.

3. Tanaka H. Fetal alcohol syndrome: a Japanese perspective. Ann Med. 1998;30:21-6.

4. May PA, Brooke L, Gossage JP, Croxford J, Adhams C, Jones KL et al. Epidemiology of fetal alcohol syndrome in a South African community in the Western Cape Province. Am J Public Health. 2000;90:1905-12.

5. Jones KL. The effects of alcohol on fetal development. Birth Defects Res C Embryo Today. 2011;93:3-11

6. Flanigan EY, Aros S, Bueno MF, Conley M, Troendle JF, Cassorla F, Mills JL. Eye malformations in children with heavy alcohol exposure in utero. J Pediatr. 2008;153:391-5.

7. Strömland K. Ocular abnormalities in the fetal alcohol syndrome. Acta Ophthalmol Suppl. 1985;171:1-50.

8. Chan T, Bowell R, O'Keefe M, Lanigan B. Ocular manifestations in fetal alcohol syndrome. Br J Ophthalmol. 1991;75:524-6.

9. Strömland K. Ocular involvement in fetal alcohol syndrome. Surv Ophthalmol. 1987;31:277-84.

10. Ribeiro IM, Vale PJ, Tenedorio PA, Rodrigues PA, Bilhoto MA, Pereira HC. Ocular manifestations in fetal alcohol syndrome. Eur J Ophthalmol. 2007;17:104-9.

11. Strömland K, Pinazo-Durán MD. Ophthalmic involvement in the fetal alcohol syndrome: clinical and animal studies. Alcohol Alcohol. 2002;37:2-8.

12. Guizzetti M, Zhang X, Goeke C, Gavin DP. Glia and neurodevelopment: focus on fetal alcohol spectrum disorders. Front Pediatr. 2014;2:123.

13. Tenkova T, Young C, Dikranian K, Labruyere J, Olney JW. Ethanol-induced apoptosis in the developing visual system during synaptogenesis. Invest Ophthalmol Vis Sci. 2003;44:2809-17.

14. Pinazo-Duran MD, Renau -Piqueras J, Guerri C. Development changes in the optic nerve related to ethanol consumption in pregnant rats: analysis of the ethanol-exposed optic nerve. Teratology. 1993;48:305-
22.

15. Harris SJ, Wilce P, Bedi KS. Exposure of rats to a high but not low dose of ethanol during early postnatal life increases the rate of loss of optic nerve axons and decreases the rate of myelination. J Anat. 2000;197:477-85

16. Samorajaski T, Lancaster F, Wiggins RC. Fetal ethanol exposure: a morphometric analysis of myelination in the optic nerve. Int $\mathrm{J}$ Dev Neurosci. 1986;4:369-74.

17. Wakakura M, Alvarez E. A simple clinical method of assessing patients with optic nerve hypoplasia. The disc-macula distance to disc diameter ratio (DM/DD). Acta Ophthalmol. 1987;65:612-7.

18. Hellström A, Chen $Y$, Strömland K. Fundus morphology assessed by digital image analysis in children with fetal alcohol syndrome. J Pediatr Ophthalmol Strabismus. 1997;34(:17-23.

19. Hellström A. Optic nerve morphology may reveal adverse events during prenatal and perinatal life-digital image analysis. Surv Ophthalmol. 1999:44:63-73.

20. Beuchat L, Safran AB. Optic nerve hypoplasia: papillary diameter and clinical correlation. J Clin Neuroophthalmol. 1985;5:249-53.

21. Pilat A, Sibley D, Mclean RJ, Proudlock FA, Gotlob I. High-resolution imaging of the optic nerve and retina in optic nerve hypoplasia Ophthalmology. 2015;122:1330-9

22. Strömland K. Visual impairment and ocular abnormalities in children with fetal alcohol syndrome. Addict Biol. 2004;9:153-7.

23. Vernescu RM, Adams RJ, Courage ML. Children with fetal alcohol sprectum disorder show an amblyopia-like pattern of vision deficit. Dev Med Child Neurol. 2012;54:557-62.

24. Leung MM, Huang RY, Lam AK. Retinal nerve fiber layer thickness in normal Hong Kong chinese children measured with optical coherence tomography. J Glaucoma. 2010;19:95-9.

25. Jun JH, Lee SY. The effects of optic disc factors on retinal nerve fiber layer thickness measurement in children. Korean J Ophthalmol. 2008;22:115-22 